\title{
Redesign and Structural analysis of agitator shaft for reactor pressure vessel
}

\author{
Sumit R.Desai ${ }^{\#^{*}}$, S.Y.Gajjal ${ }^{\#}$ and Kulloli ${ }^{\#}$ \\ \#Department of Mechanical Engineering, NBNSCOE, Savitribai Phule University of Pune, Ambegaon (Bk), Pune, India 411041
}

Accepted 02 March 2016, Available online 15 March 2016, Special Issue-4 (March 2016)

\begin{abstract}
Agitator shaft is important component of agitation system used in reactor pressure vessel. Failure of agitator shaft leads to breakdown of whole plant. The existing agitator undergoes deflection; not suitable for uniform mixing of fluid, also time required for agitation is more. One of the major parameter to increase the overall performance of agitator shaft is to reduce deflection. The work is carried out to reduce deflection by optimizing the design or by using different materials like SS, SS304 and SS305. This dissertation work is aimed to redesign existing single impeller agitator shaft by using SS316 material with double impeller. This results in improved overall performance by minimizing deflection of agitator. Redesigned impeller agitator shaft is modeled using CAD modeling software. Stress analysis of the shaft subjected to combined loading was done using FEA software. These results were compared with experimental values observed by company. It is observed that the deflection of redesigned agitator is $0.8375 \mathrm{~mm}$ which is reduced by $14.997 \%$ than exiting agitator.
\end{abstract}

Keywords: Agitator shaft, Bending stress, Impeller, Reactor pressure vessel, Torsional stress

\section{Introduction}

Pressure vessels widely used in reactor technology, the chemical industry, marine and space engineering. A pressure vessel is a closed container designed to hold gases or liquids. Agitators are devices that are used to stir or mix fluids, especially liquids, which is one of the basic mechanical process engineering operations. Industrial agitators are machines used in industries that process products in the chemical, food, pharmaceutical and cosmetic industries, in a view of mixing liquids together, promote the reactions of chemical substance, keeping homogeneous liquid bulk during storage. So as to impart modifications if necessary to keep the vibrations of the vessel within the limits from the point of view of proper functioning of the vessel and safety issues. Agitators are used for the homogenization of liquids or liquid-solid mixtures by generating horizontal and vertical flows

Agitator shaft is a rotating member usually of circular cross-section which is used for agitation or mixing purpose. Elements such as impeller, coupling, bearing are mounted on the shaft. In design it is usually possible to locate the critical areas, size these to meet the strength requirements, and then size the rest of the shaft to meet the requirements of the shaft-supported elements. Agitator shaft is a critical component used in reactor pressure vessel. It carries a load of impellers.

*Corresponding author: Sumit R.Desai
Along the years, many unexpected failures of equipments and various machines have occurred throughout the industrial world. A number of these failures have been due to poor design. However, it has been discovered that many failures have been caused by preexisting notches or flaws in materials that initiate cracks that grow and lead to fracture.

In the chemical industry, many types of vessels, which are also called as reactor vessel, with agitator, are being used largely for the purpose of homogeneous mixing of the product. Since a chemical plant runs continuously for 24 hours per day, to achieve optimum plant reliability is the main goal of the chemical industry. Thus, in case an equipment failure that may occur at unexpected instant results in production shutdown and its related costs. Such events occur predominantly in rotating equipment, e.g. in large agitators. Therefore, they are responsible for significant loss of plant availability. In fact, an agitator shaft with a notch or scratch can be cracked and leaded to failure easily under the combined stresses created by fluctuating forces during operation.

When the existing agitator is not suitable and does not provide a comfortable working condition to the workforce thus creating problems in the output of then different parameters of the organization efficiency like quality, quantity, delivery schedule and work force satisfaction.

Literature review reveals that the previous work carried out on Agitator shaft was focused on failure 
aspect. In this paper, Agitator shaft design modification carried out for selection of another material, motor selection, mounting of agitator, no. of impeller used and analyzed for structural analysis

\section{Material Selection}

The agitator shaft was made from a standard AISI type 316 stainless steel that is Austenitic grade. Austenitic stainless steels are the most widely used and while most are designated in the 300 series. Especially types 304 and 316 are highly ductile and though grades and they are utilized for a broad range of equipment and structures. Austenitic grade steels are non-magnetic and non heat-treatable steels that are usually Annealed and cold worked.

They provide excellent corrosion and heat resistance with good mechanical properties over a wide range of temperatures, respond very well to forming operations, and are readily welded. When fully annealed, they are not magnetic. Austenitic grade steels have $\gamma$ - austenite structure which can dissolve up to $2 \% \mathrm{C}$ in solid solution and has FCC (facecentered cubic) crystal lattice. The Chemical Composition and some Mechanical Properties (acc. to ASTM) of Type 316 SS are given in Table 1 and Table 2.

Table 1 Chemical Composition of AISI 316 SS

\begin{tabular}{|c|c|}
\hline Element & Weight, $\%$ \\
\hline $\mathrm{C}$ & 0.08 \\
\hline $\mathrm{Cr}$ & $18-20$ \\
\hline $\mathrm{Ni}$ & $8-10$ \\
\hline $\mathrm{Mn}$ & 2.0 \\
\hline $\mathrm{Si}$ & 0.75 \\
\hline $\mathrm{P}$ & 0.045 \\
\hline $\mathrm{S}$ & 0.03 \\
\hline Iron & Bal. \\
\hline
\end{tabular}

Table 2 Mechanical Properties of SS316 Annealed

\begin{tabular}{|c|c|c|}
\hline Property & Unit & Value \\
\hline Density & $\mathrm{kg} / \mathrm{m}^{3}$ & 7800 \\
\hline Poison's Ratio & - & 0.30 \\
\hline Elastic Modulus & $\mathrm{GPa}$ & 193 \\
\hline Shear Modulus & $\mathrm{GPa}$ & 86 \\
\hline Tensile Strength & $\mathrm{MPa}$ & 515 \\
\hline Yield Strength & $\mathrm{MPa}$ & 205 \\
\hline
\end{tabular}

\section{Design of agitator}

\section{Power Requirement for Agitator}

The power consumption in an agitated vessel is a function of the variables that is:

$$
\begin{aligned}
& P=\phi(n, D, g, \mu, g, \rho) \\
& \text { Where: } \\
& \text { n: speed } \\
& \text { Da: impeller dia. }
\end{aligned}
$$
$\mu$ : viscosity
g: acceleration of gravity
$\rho$ : density

\section{A. Power Number (Np)}

The Power Number (Np) from which the power will be calculated can be written like this:

$$
\begin{aligned}
& \mathrm{Np}=\mathrm{P}^{*} \mathrm{~g} / \mathrm{n}^{3} \mathrm{Da}^{5} \rho \\
& \mathrm{nDa}^{2} \rho / \mu=\mathrm{N}_{\mathrm{Re}} \text { Reynolds Number } \\
& \mathrm{n}^{2} \mathrm{Da} / \mathrm{g}=\mathrm{N}_{\mathrm{fr}} \quad \text { Froude Number } \\
& \mathrm{N}_{\mathrm{Re}}=3.89 \times 10^{5} \\
& \mathrm{~N}_{\mathrm{Re}}>10000 \text { (flow is fully turbulent) }
\end{aligned}
$$

Because the flow is fully turbulent, power number is only function of shape factors.

From the graphs given in (Chem. Eng. Handbook, 1973)

From power curve

$$
\begin{gathered}
\frac{W}{D a}=150 / 900 \\
=1 / 5
\end{gathered}
$$

$N p=4$ found for impeller with two flat blades

$$
\begin{aligned}
& \text { B. Power Required } \\
& \qquad \begin{array}{l}
\mathrm{P}=\mathrm{Np} \times \rho \times \mathrm{N} 3 \times \mathrm{Da}^{5} / g \times 75 \\
\mathrm{P}=\mathrm{P}_{1}+\mathrm{P}_{2} \\
=10.582 \\
\text { Where } \\
\mathrm{P}=\text { Total Power Required } \\
\mathrm{P}_{1}=\text { Power required to } 1^{\text {st }} \text { impeller } \\
\mathrm{P}_{2}=\text { Power required to } 2^{\text {nd }} \text { impeller }
\end{array}
\end{aligned}
$$

Also consider $10 \%$ gland losses and $20 \%$ transmission losses

$$
\begin{aligned}
& \mathrm{P}=10.927 \mathrm{hp} \\
& \text { So selected Next std. }
\end{aligned}
$$

$\mathrm{P}=15 \mathrm{hp} \quad$........ Motor selected

\section{Design of Agitated shaft}

\section{A. Rated torque}

$$
\begin{gathered}
\mathrm{P}=2 \pi \mathrm{NT}_{\mathrm{r}} / 4500 \\
\text { Where } \\
\mathrm{P}=\text { Total Power Required } \\
\mathrm{N}=\text { Agitated speed in rpm } \\
\mathrm{T}_{\mathrm{r}}=\text { Rated torque } \\
\mathrm{T}_{\mathrm{r}}=93417.03 \mathrm{Nm}
\end{gathered}
$$

\section{B. Design of shaft on Pure Bending}

By bending theory

$$
\begin{gathered}
\mathrm{M}_{\mathrm{b}}=\pi / 32 \times 6_{\mathrm{b}} \times \mathrm{d}^{3} \\
\text { Where } \mathrm{M}_{\mathrm{b}}=\text { Bending moment } \\
6_{\mathrm{b}}=\text { bending stress } \\
\mathrm{F}_{\mathrm{m}}=\mathrm{T}_{\mathrm{m}} /\left(0.75 \times \mathrm{R}_{\mathrm{b}}\right) \\
\text { Where } \mathrm{F}_{\mathrm{m}}=\text { impeller force } \\
\mathrm{T}_{\mathrm{m}}=\text { Max torque }
\end{gathered}
$$




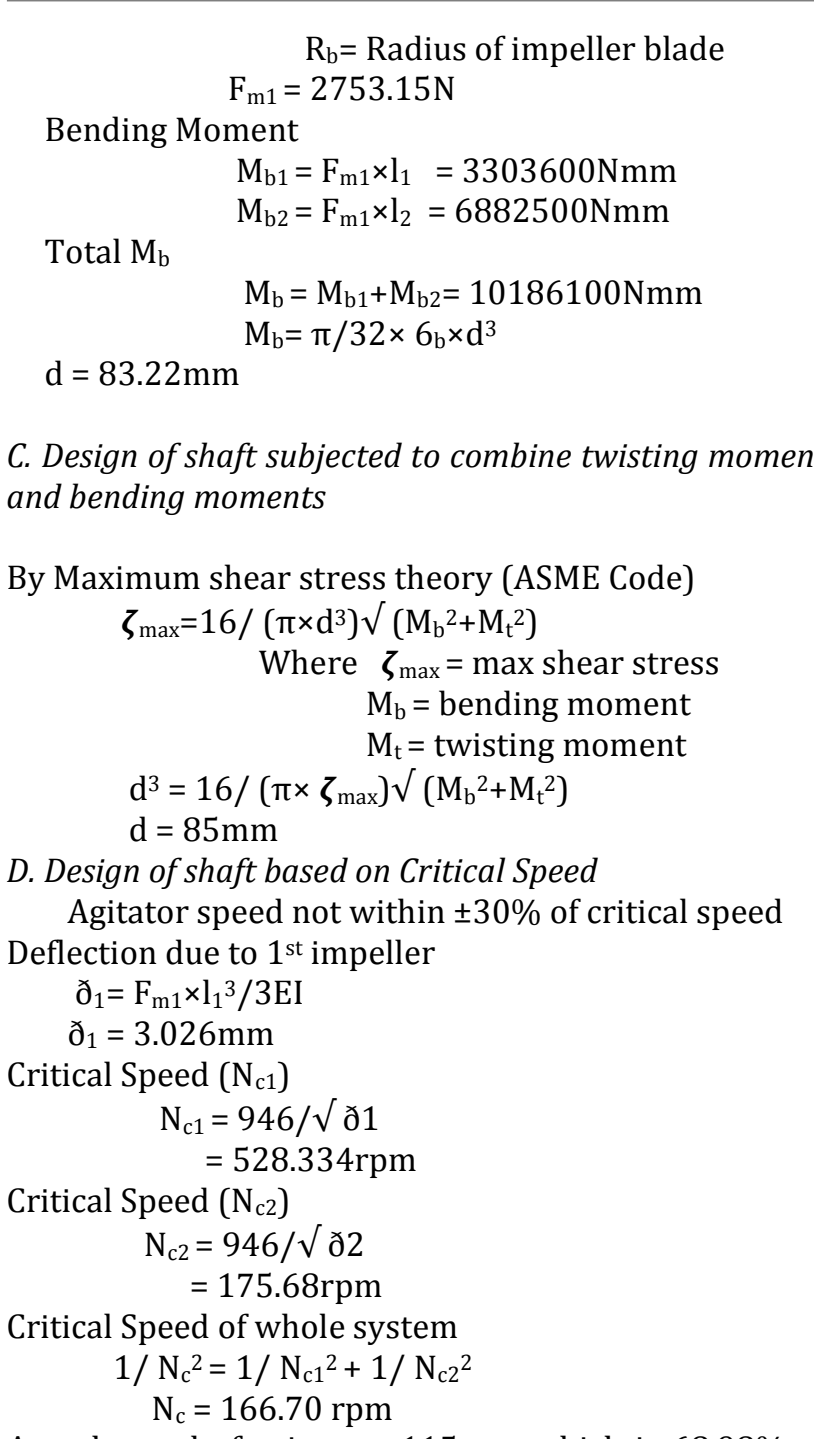

Actual speed of agitator $=115 \mathrm{rpm}$ which is $68.98 \%$ of critical speed, hence necessary to increase value of critical speed.

So,

\section{Choose next standard $d=90 \mathrm{~mm} \quad \ldots . . .$. shaft diameter}

Actual speed is $61.98 \%$ of critical speed, therefore selected $90 \mathrm{~mm}$ dia. of agitator shaft is satisfactory, which is not between 70 to $130 \%$.

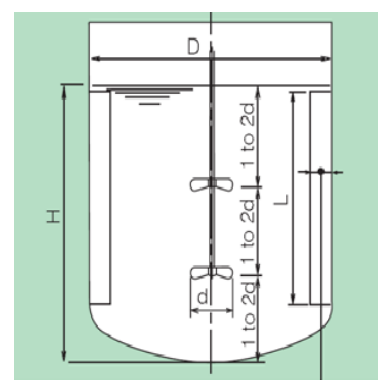

Figure 1 Agitator mounted at the center

Agitator mounted at the center of tank and baffles plates are attach on inner walls of tank to crate vertical convection and turbulence. Baffles are needed to prevent vortexing and rotation of the liquid mass as a whole.

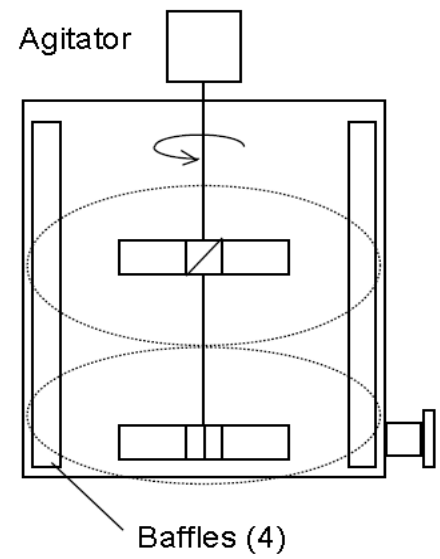

Figure 2 Agitator shaft with Baffles

Antiswirl baffles are required in larger industrial fluidmixing operations. Baffles are used for center-shaft, top-mounted mixers to prevent vortexing. Baffles also promote top-to-bottom turnover and represent good mixing practice. The most usual arrangement is to have four baffles paced at $90^{\circ}$.

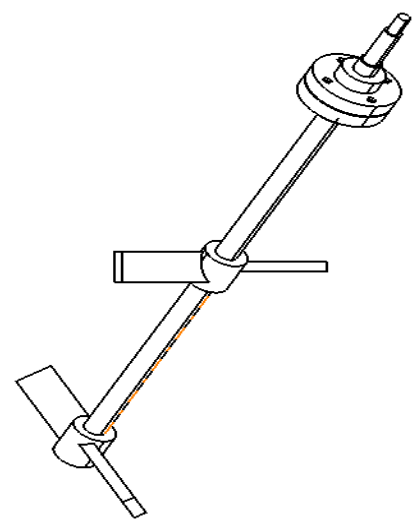

Figure 3 CAD Model of Double impeller Agitator

\section{Structural Analysis}

Static analysis calculate the effects of steady loading condition on a structure, while ignoring inertia and damping effects, such as those caused by time varying loads. A static analysis can include steady inertia loads such as gravity and rotational velocity and varying loads that can be approximated as static loads. Static analysis determines the displacements, stresses, strains, and forces in structure or components caused by loads that do not induce significant inertia and damping effects. Steady loading and response conditions are assumed; that is the loads and structures responses are assumed to vary slowly with respect to time. A static analysis result of structural displacements, stresses and strains and forces in structures for components caused by loads will give a clear idea about whether the structure or components will withstand for the applied maximum forces. If the 
stress values obtained in this analysis crosses the allowable values it will result in the failure of the structure in the static condition itself. To avoid such a failure, this analysis is necessary.

Assigning material properties: Material properties Young's modulus \& Poisson's ratio are defined. Also other properties like coefficient of expansion, coefficient of friction, thermal conductivity, damping effect, specific heat etc. are defined if required

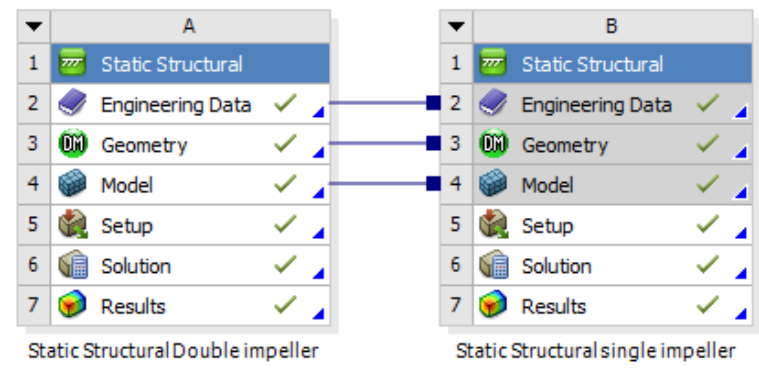

Figure 4 Static structural Analysis

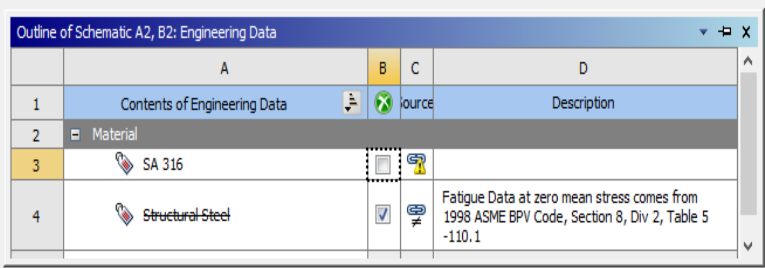

Figure 5 Engineering Data

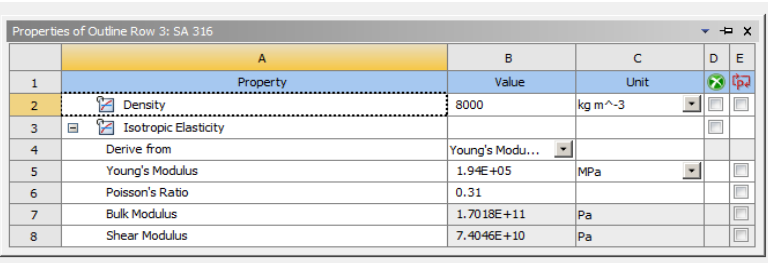

Figure 6 Properties of Material

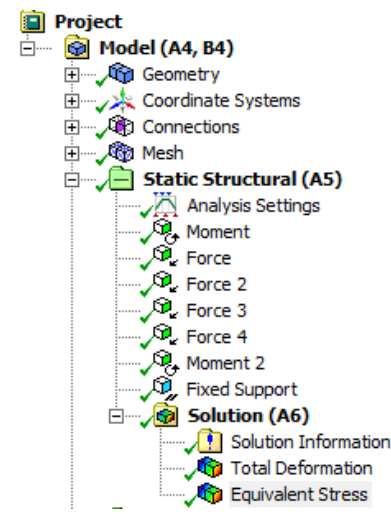

Figure 7 Flow diagram of Double impeller shaft

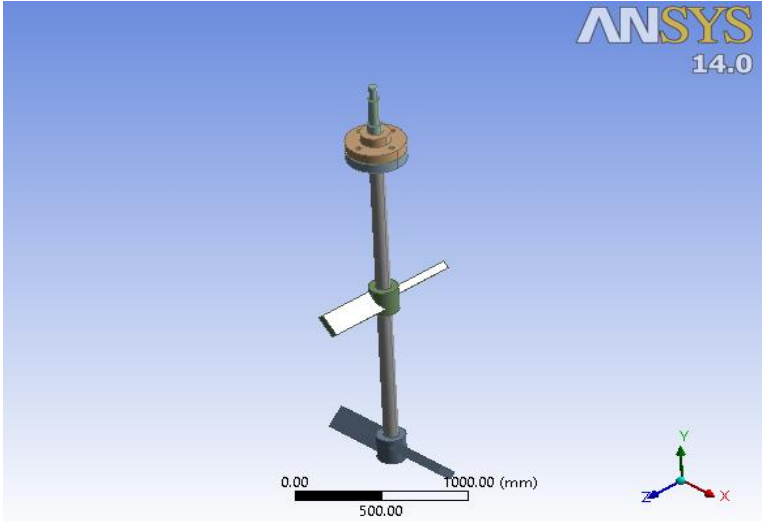

Figure 8 CAD Geometry of Double impeller Agitator Shaft

Mesh generation is a process of dividing the structure continuum into a number of discrete parts or finite elements. If the mesh is finer, the results are also better but the analysis time is longer. Therefore, a compromise between accuracy \& solution speed is usually made.

Fine mesh was used to increase the number of elements at the vicinity of the critical points. The auto mesh generator uses an algorithm that minimizes element distortion. 3-D linear tetrahedral solid 186 and solid 187 elements with global element size of $30 \mathrm{~mm}$ and local element size of $10 \mathrm{~mm}$ were considered at the critical locations. After discretization 578501 nodes and 129033 elements were created

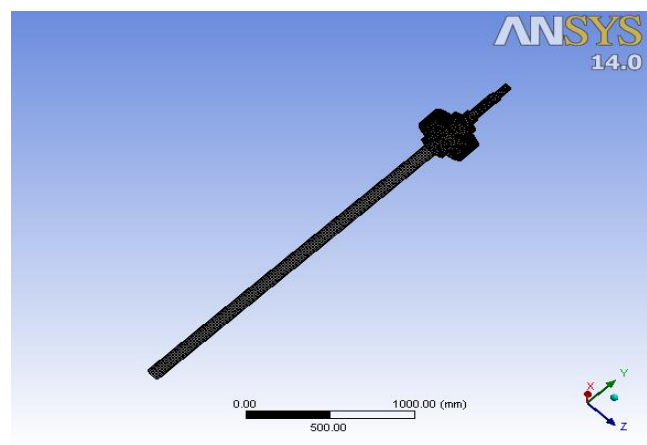

Figure 9 Meshing of Double impeller Agitator shaft

Apply loads: - Some types of load are usually applied to the analysis model. The loading may be in the form of a point load, pressure or displacement in a stress analysis.

Applying boundary conditions: - If you apply a load to the model, then in order to stop it accelerating through the computer's virtual ether (mathematically known as a zero pivot), at least one constraint or boundary condition must be applied. Structural boundary conditions are usually in the form of zero displacements. 


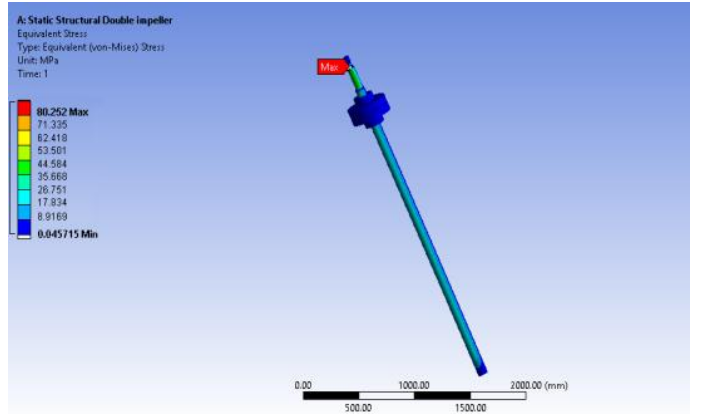

Figure 10 Equivalent / von-mises stresses of Double impeller Agitator shaft

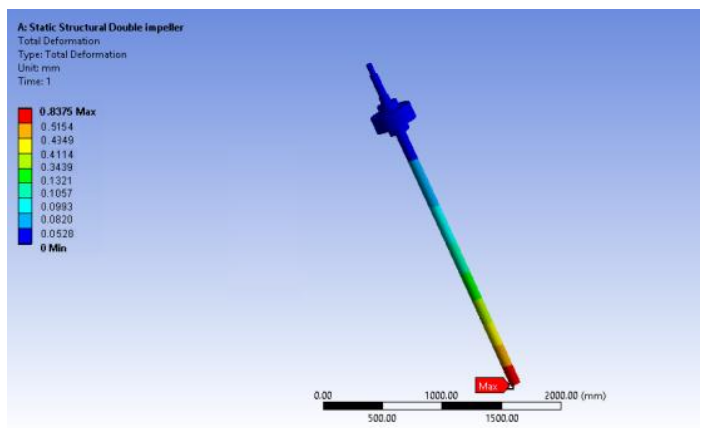

Figure 11 Deformation of Double impeller Agitator shaft

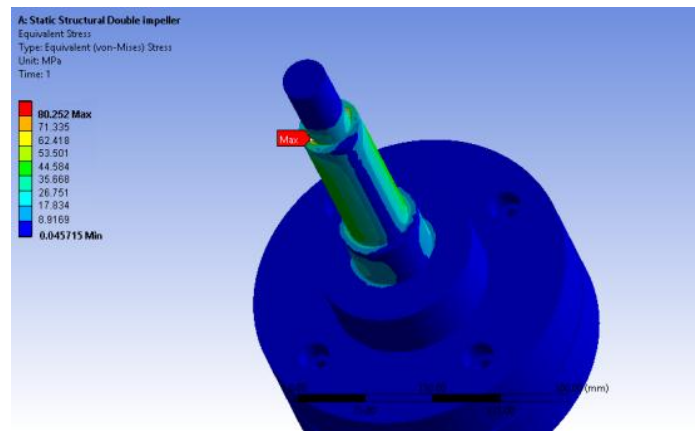

Figure 12 Enlarge view of Max Equivalent / von-mises stresses of Agitator shaft

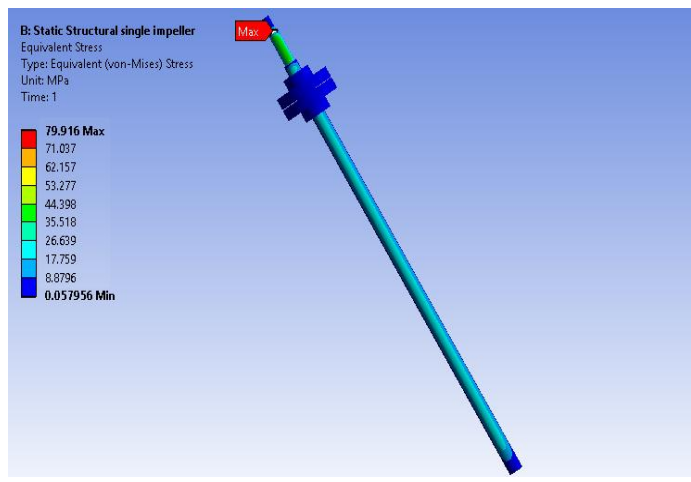

Figure 13 Equivalent / von-mises stresses of Single impeller Agitator shaft

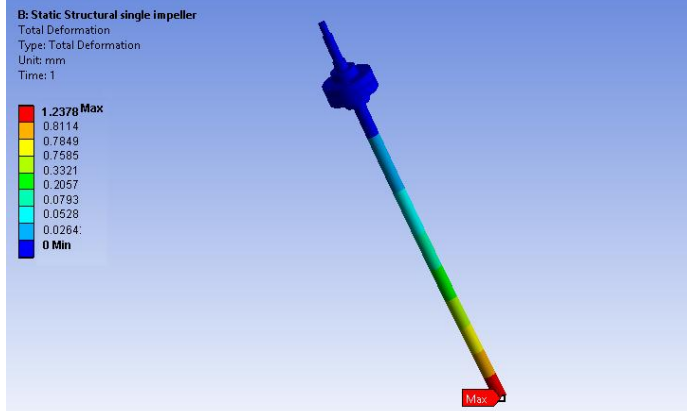

Figure 14 Total Deformation of Agitator shaft

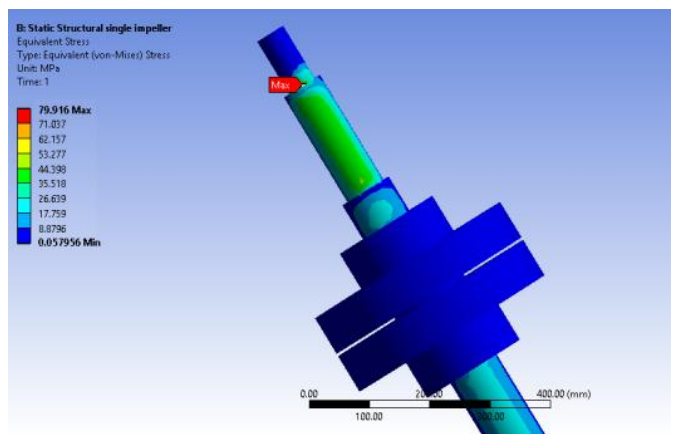

Figure 15 Enlarge View of Max Equivalent / von-mises stresses of Single impeller Agitator shaft

\section{Results \& discussions}

Table 3 Design Modification

\begin{tabular}{|c|c|c|c|}
\hline $\begin{array}{c}\text { Sr. } \\
\text { No. }\end{array}$ & $\begin{array}{c}\text { Design } \\
\text { Parameter }\end{array}$ & Modified & Previous \\
\hline 1. & Motor & $15 \mathrm{hp}$ & $10 \mathrm{hp}$ \\
\hline 2. & Material & SS316 & Structural steel \\
\hline 3. & $\begin{array}{c}\text { Diameter of } \\
\text { shaft }\end{array}$ & $90 \mathrm{~mm}$ & $60 \mathrm{~mm}$ \\
\hline 4. & No. of impeller & Two & One \\
\hline 5. & $\begin{array}{c}\text { Mounting of } \\
\text { agitator }\end{array}$ & Top \& Center & Eccentrically \\
\hline 6. & Baffle plates & Provided & No \\
\hline
\end{tabular}

Table 4 Equivalent stress by FEA \& Analytical Approach

\begin{tabular}{|c|c|c|c|c|}
\hline & Parameter & Unit & $\begin{array}{c}\text { FEA } \\
\text { Result }\end{array}$ & $\begin{array}{c}\text { Analytica } \\
\text { l } \\
\text { Result }\end{array}$ \\
\hline 1 & $\begin{array}{c}\text { Double impeller } \\
\text { shaft }\end{array}$ & $\mathrm{MPa}$ & 80.916 & 90.45 \\
\hline 2 & $\begin{array}{c}\text { Single impeller } \\
\text { shaft }\end{array}$ & $\mathrm{MPa}$ & 79.916 & 85.68 \\
\hline
\end{tabular}

Table 5 Deflection by FEA \& Expt. Approach

\begin{tabular}{|c|c|c|}
\hline Parameter & $\begin{array}{c}\text { Deflection by } \\
\text { FEA Method } \\
\text { (mm) }\end{array}$ & $\begin{array}{c}\text { Deflection by } \\
\text { Expt.(mm) }\end{array}$ \\
\hline $\begin{array}{c}\text { Double impeller } \\
\text { shaft }\end{array}$ & 0.8375 & 0.8746 \\
\hline $\begin{array}{c}\text { Single impeller } \\
\text { shaft }\end{array}$ & 1.237 & 1.469 \\
\hline
\end{tabular}




\section{Conclusions}

In this dissertation work a methodology to analysis and design of Agitator shaft is presented. During this work following conclusions are found,

1) Selecting another material for agitator increase strength, ductility\& corrosion resistance.

2) By increasing no. of impellers improves mixing time, provide balancing \& reduce deformation.

3) By mounting agitator shaft at centre done provision for baffle plates in vessel.

4) Provision of baffle plates gives uniform mixing

5) Equivalent Stress generated in double impeller shaft is approximately same as that of single impeller shaft.

6) Deflection in Double impeller shaft is less as compare that of single impeller shaft.

7) The deformation and Equivalent stress are within the permissible limit.

\section{References}

A.Goksenli, I.B. Eryurek (2009), Failure analysis of a mixing shaft. 'Engineering failure analysis 16 '
Saeed Asiri, et al., 2012, Design and Implementation of Differential Agitators to Maximize Agitating Performance. Saudi Abrbia, 2(6): 98-112.

Domanskii,.et al.,Large size Agitator with Precession Impeller for ore Slurries-Study, Design, Tests

D. S. Dickey and J. B. Fasano, (2004), Mechanical Design of Mixing equipment

Karray, S., Driss, Z., Kchaou, H., Abid, M.S., 2011, Design of Agitator in a stirred vessel equipped with an anchor impeller, Journal of Mechanical Science and Technology, 25 (7), 1-12.

B.Somi Naidu, M.K.Naidu \& S.Srinivasa Rao-Design of ShaftBlade Assembly for Effective Utilization of Mud Used In Oil and Gas Drilling

Driss, Z., Karray, S., Kchaou, H., and Abid, M.S., 2007, Computer Simulations of Fluid-Structure Interaction Generated by a Flat-Blade Paddle in a Vessel Tank, International Review of Mechanical Engineering (I.RE.M.E.), $1,608-617$

V.B.Bhandari, Design of Machine Element, (Tata McGraw-Hill Publication. New Delhi.2004)

R. S. Khurmi Machine Design S. Chand \& Company Pvt. Ltd. Delhi.

ANSYS, ANSYS User's Manual, Version 14.5, ANSYS Inc, 2011. 